\title{
EU Enlargement, the CAP and the Cost of Direct Payments: A Note
}

\author{
Robert W. Ackrill ${ }^{1}$ \\ Department of Economics and Politics \\ The Nottingham Trent University \\ Burton Street \\ Nottingham \\ NG1 4BU \\ robert.ackrill@ntu.ac.uk
}

Negotiations over EU enlargement have highlighted difficulties in extending the CAP - and in particular direct payments - to the applicant countries, given the spending limits agreed in Berlin in 1999. This note presents estimates of direct payment costs in the Eastern European applicants. It argues that the only way all member states in an enlarged EU can receive the same level of payments is if the payments currently prevailing in the EU15 are reduced.

\footnotetext{
${ }^{1}$ The work developing the model used in this paper (CAPCEE - The Cost of Agricultural Policy in Central and Eastern Europe), was carried out in DEFRA (Economics International) during the summer of 2001. The author extends his thanks to all colleagues there (especially Jonathan, Iain and Paul) for their help and support and to DEFRA and HM Treasury for financial support through the Challenge Fund. All results and views presented are the author's alone and should not be interpreted as indicating UK government views or policy in any way. The author also thanks two anonymous referees for very helpful comments made on an earlier version of the paper. The usual disclaimer applies, of course.
} 


\section{Introduction}

The eastward enlargement of the EU is scheduled to begin in 2004. ${ }^{2}$ By mid 2002, serious negotiations on the terms of acceding to the CAP were only just beginning. A key concern is the amount of CAP spending the EU can afford to offer the new member states, given the tight spending limit agreed at Berlin covering the period 2000-2006. Under the CAP there are three types of payment. Rural Development will not be discussed in detail here. It is noted simply that this is important for the future of agricultural and rural infrastructure in the applicant countries and thus needs to be made. Second there are payments related to price support. Since price support alters price levels, this needs to be extended to the new members to avoid different prices within the Single European Market.

Third there are direct payments. Although long-available for some commodities, they have only been a core part of CAP support since 1992. Initially designed as specific compensation for a specific price cut, the 1999 reform saw this role change. The rise in direct payments was, however, less than the cut in price. The new policy of modulation, where countries can skim off a percentage of direct payments and recycle the money into rural development projects, has further reduced the link between payments and previous price levels. ${ }^{3}$ Direct payments therefore represent a shift in the basis of CAP support. This is crucial to the enlargement debate, because the issue is not compensation for price cuts the farmers in eastern Europe did not face, but about basic issues of support under the CAP.

Given the importance of rural development and the characteristics of price support, the EU will be granting these policies and transfers. The focus is thus primarily on the level of direct payments that can be afforded. Applicants have sought parity with the EU15, whilst the EU has shifted from opposing granting any payments to phasing-in payments over 10 years, starting at 25\% of EU15 levels. ${ }^{4}$ Direct payments can be offered at differentiated rates to different farmers and trade distortion can be avoided

\footnotetext{
${ }^{2}$ Bulgaria and Romania will join later.

${ }^{3}$ The Commission intends this to continue. See European Commission 2002b.

${ }^{4}$ Ackrill 2000, pages 160-163, considers this debate in more detail.
} 
if payments are decoupled. ${ }^{5}$ Whilst this challenges the notion of a common agricultural policy, this debate has been driven by the spending limit agreed at Berlin. This paper assesses the level of direct payments the EU can afford, given the Berlin spending limit and reasonable assumptions about rural development and price support costs. This complements other studies which estimate the cost of enlargement but do not consider explicitly the Berlin spending limit.

\section{The Model}

CAPCEE estimates the budget cost of applying the CAP in central and eastern European countries. Key values used in estimating direct payment costs (detailed in the Appendix) are determined endogenously using 1995-1999 data, the period originally requested by the Commission for data from the applicant countries. The estimates have been compared with the Commission 'Issues Paper' (European Commission 2002a) to ensure their appropriateness. The data in the Issues Paper were not used since this contains EU offers and applicant requests, but not final agreed values. Nor does it have data for Bulgaria and Romania. The estimates generated in CAPCEE do, however, fall within the range in the Issues Paper and therefore represent feasible outcomes from negotiation between the EU and applicants.

\section{Results and Discussion}

The analysis assumes the accession of the CEE8 in 2004, with Bulgaria and Romania joining in 2008. Even if this is not exactly what happens, it allows the impact of a staggered accession to be shown. This is especially important for Romania, predicted to be a significant beneficiary from the CAP. Tables 1 and 2 show the estimated cost of direct payments by country and by main commodity. As expected, Poland is the largest beneficiary but Hungary and, later, Romania also receive significant sums. Sectoral spending is dominated by arable costs. Beef spending is extremely difficult to estimate given the lack of data identifying the numbers of animals eligible for support under this complex regime (see the Appendix for more details). ${ }^{6}$

\footnotetext{
${ }^{5}$ Cahill (1997) suggests the 1992 arable payments were between 70\% and 100\% decoupled.

${ }^{6}$ Note that European Commission (2002a) does not contain cost estimates to use as a comparison. Silvis et al estimate higher beef costs and lower arable costs, but very similar costs overall. They base their calculations, however, on the narrower data period 1996-1998.
} 
Table 1: Estimated Direct Payment Costs by Country ( $€$ million)

\begin{tabular}{lrrrrr}
\hline & $\mathbf{2 0 0 4}$ & $\mathbf{2 0 0 5}$ & $\mathbf{2 0 0 6}$ & $\mathbf{2 0 0 7}$ & $\mathbf{2 0 0 8}$ \\
\hline Bulgaria & & & & & 595 \\
Czech Republic & 630 & 652 & 674 & 697 & 696 \\
Estonia & 60 & 65 & 71 & 76 & 76 \\
Hungary & 1052 & 1069 & 1087 & 1104 & 1104 \\
Latvia & 82 & 89 & 95 & 102 & 102 \\
Lithuania & 242 & 258 & 274 & 290 & 289 \\
Poland & 2152 & 2255 & 2358 & 2461 & 2461 \\
Romania & & & & & 1717 \\
Slovakia & 312 & 321 & 330 & 338 & 338 \\
Slovenia & 59 & 64 & 69 & 74 & 74 \\
\hline Total & 4588 & 4773 & 4957 & 5142 & 7452 \\
\hline
\end{tabular}

Table 2: Estimated Direct Payment Costs by Principal Commodity (€ million)

\begin{tabular}{lrrrrr}
\hline & $\mathbf{2 0 0 4}$ & $\mathbf{2 0 0 5}$ & $\mathbf{2 0 0 6}$ & $\mathbf{2 0 0 7}$ & $\mathbf{2 0 0 8}^{1}$ \\
\hline Arable & 3980 & 3981 & 3981 & 3981 & 5761 \\
Dairy & & 186 & 371 & 557 & 605 \\
Beef & 549 & 548 & 547 & 545 & 711 \\
Sheep & 52 & 52 & 52 & 52 & 367 \\
\hline Total $^{2}$ & 4588 & 1773 & 4987 & 5142 & 7452
\end{tabular}

Notes

1 - CEE8 to 2007, CEE10 for 2008.

2 - includes minor sums for olive oil, tobacco, 'fibre plants' and 'other plants'.

Table 3 focuses on the margin under the Berlin spending ceiling left for direct payments, once Rural Development and price support have been taken into account. Note that because the Berlin financial perspective only covers the period to 2006, some simple assumptions are made to extend the data through to 2008. Spending on Rural Development for 2004 to 2006 has been taken directly from the Issues Paper. The values for 2007 and 2008 are derived by a simple linear extrapolation of the previous three years' Payment Appropriation figures. The Berlin spending ceiling for 2004 to 2006 rises at a falling rate, so the estimates for 2007 and 2008 assume this 
declining rate of increase continues. This implies no further adjustments are made to accommodate Bulgaria and Romania, a point returned to below.

Table 3: CAP Transfers Affordable under the Berlin Agreement ( $€$ million)

\begin{tabular}{clrrrrr}
\hline Scenario & $\mathbf{2 0 0 4}$ & $\mathbf{2 0 0 5}$ & $\mathbf{2 0 0 6}$ & $\mathbf{2 0 0 7}$ & $\mathbf{2 0 0 8}$ \\
\hline & Berlin Spending Ceiling & 2450 & 2930 & 3400 & 3860 & 4310 \\
& Rural Development & $\mathbf{7 4 8}$ & 1187 & 1730 & 2221 & 2712 \\
\hline a & (Price Support: CAPCEE) & 468 & 532 & 586 & 480 & 479 \\
& Margin for Direct Payments & 1234 & 1211 & 1084 & 1159 & 1119 \\
& Projected Direct Payments & 4588 & 4773 & 4957 & 5142 & 7452 \\
& DP Affordable (\%) & 27 & 25 & 22 & 23 & 15 \\
\hline b & (Price Support: Issues Paper) & 516 & 749 & 734 & & \\
& Margin for Direct Payments & 1186 & 994 & 936 & & \\
& Projected Direct Payments & 4588 & 4773 & 4957 & & \\
& DP Affordable (\%) & 26 & 21 & 19 & & \\
\hline c & Margin for Direct Payments & 1234 & 1211 & 1084 & 1159 & 1119 \\
& Projected Direct Payments & 4735 & 4920 & 5105 & 5292 & 7479 \\
& DP Affordable (\%) & 26 & 25 & 21 & 22 & 15 \\
\hline
\end{tabular}

Notes:

See the text for the basis of the 2007 and 2008 extension of the Berlin spending ceiling, Rural Development spending and the basis for calculating the margin available for direct payments under each scenario.

The first set of results (scenario 'a') has a margin for direct payments based on Rural Development spending as described above and price support costs taken from CAPCEE. The direct payment estimates also come from CAPCEE. These results are then compared with those from other studies, both to test the robustness of the CAPCEE estimates and, for price support costs, to act as a test of the sensitivity of the results given uncertainties over underlying assumptions of future world prices, dollar/euro exchange rates, etc. Scenario 'b' differs from 'a' by taking price support 
estimates from the Issues Paper. Scenario 'c' differs from 'a' in its use of direct payment estimates taken from Silvis et al (2001). ${ }^{7}$

We do not consider price support costs from any other study since, in particular, they do not include current cereals market conditions, where all grains except rye are exported without subsidy. Suffice it to say if estimates from other studies were included, the margin for direct payments would be reduced considerably. ${ }^{8}$ Nor do we repeat the exercise with direct payment estimates from the Issues Paper as this only offers estimates of phased direct payment costs, rather than full uncapped payments.

Table 3 shows, first, that the estimates from CAPCEE are in line with those from other major studies. Second, all scenarios show that the EU cannot afford to offer the new member states the same level of direct payments as the EU15 given current payment levels, reasonable estimates of price support expenditure, expected Rural Development spending and the Berlin Summit spending ceiling. That is, this key conclusion is insensitive to the different cost estimates presented.

Moreover, the Issues Paper proposes granting direct payments to new member states at $25 \%$ of EU15 values, rising by five percentage points per year until "the new Member States reach in 2013 the support level then applicable” (European Commission 2002a, page 6, emphasis added). Table 3 questions whether the EU will be able, ceteris paribus, even to raise direct payments above 25\% of EU15 rates, under any scenario. For 2008 and the accession of Bulgaria and Romania, the estimates in Table 3 assume no adjustment to Rural Development spending nor the spending ceiling. If we relax the second assumption, the spending ceiling would need to rise by about $€ 745$ million (or nearly 20\%) just to permit payments to the CEE10 at 25\% of EU15 levels - and more if extra Rural Development resources are to be made available.

\footnotetext{
${ }^{7}$ Adjusted to CEE8 for 2004-2007, CEE10 for 2008, based on their Table A2.2, page 59.

${ }^{8}$ For example, Silvis et al (2001) estimate 'Market Expenditure' at about €2 billion for the CEE8 and $€ 2.7$ billion for the CEE10. See also Swinnen (2002).
} 


\section{Concluding Remarks}

This paper has shown that the goal of granting all member states in an enlarged EU identical CAP direct payments will require further change to the policy - be it a rise in the spending limit or a reduction in the value of direct payments currently granted. It has also raised serious doubts over the ability of the EU currently to afford much more than $25 \%$ of current payment levels in the new member states. Moreover, both conclusions hold even when other studies' estimates of future CAP spending are used.

The earlier quote from the Issues Paper also implies change is required. What is of concern, however, is the ability of EU countries to agree a reduction in direct payments. In its 'Mid-Term Review' of the CAP (European Commission 2002b), the Commission proposed a wide-ranging set of reforms (although without any reduction in overall CAP spending). One measure is for the current modulation scheme to become compulsory, with direct payments reduced by $20 \%$. Since modulation can involve redistribution between countries implying, in effect, uncompensated cuts in direct payments for some countries, significant opposition has already been voiced - a sign of the difficulties to come. Will it be the spending limit that is sacrificed for a successful enlargement or will reform be achieved that actually sees direct payments reduced? The talks on CAP reform and EU enlargement still have much to address. 


\section{References}

Ackrill, R. W. (2000). The Common Agricultural Policy. Sheffield Academic Press for the University Association for Contemporary European Studies, Sheffield.

Cahill, S. A. (1997) Calculating the Rate of Decoupling for Crops Under CAP/Oilseeds Reform. Journal of Agricultural Economics, 48 (3), 349-378.

European Commission (2000). Prospects for Agricultural Markets, 2000-2007. Directorate General for Agriculture, Brussels.

European Commission (2002a) Enlargement and Agriculture: Successfully integrating the new Member States into the CAP. Issues Paper. SEC(2002)95 final. Brussels, 30.1.2002.

European Commission (2002b) Mid-Term Review of the Common Agricultural Policy. Communication from the Commission to the Council and the European Parliament. COM(2002)394 final. Brussels, 10.7.2002.

FAPRI (2000). World Agricultural Outlook, 2000-2010. Staff Report 2-00. Food and Agricultural Policy Research Institute, Iowa State University and University of Missouri-Columbia.

Silvis, H. J., C. W. J. van Rijswick and A. J. de Kleijn (2001). EU Agricultural Expenditure for Various Accession Scenarios. Report 6.01.04. Agricultural Economics Research Institute (LEI), The Hague.

Swinnen, J. F. M. (2002) Budgetary Implications of Enlargement: Agriculture. CEPS Policy Brief No. 22. Centre for European Policy Studies, Brussels.

USDA (2000). Baseline Projections, 2000-2007. United States Department of Agriculture, Washington D. C. 


\section{Appendix - The Direct Payment Calculations}

All calculations are based as far as possible on the EU approach. Unless otherwise indicated, FAO data are used.

\section{Arable}

Base yield - the average of the middle three values for the period 1995-1999, national level only (there are insufficient data to permit estimates by region, nor to distinguish between small and large farms.

Eligible area - the average of 1997-1999 data.

Set aside (effective) assumed at 5\%, assuming significant numbers of small farms. Insufficient structures data are available for an exact calculation of the effective setaside rate.

\section{Dairy}

Payment eligibility set with reference to 1999 quota levels.

Payments are phased-in at the same rate as in the EU15 (for Bulgaria and Romania, starting in 2008).

\section{Beef}

The calculations are enormously difficult, given the lack of data on numbers of animals eligible for each payment. Data came from the FAO and the (slightly more disaggregated) EU Cronos database, coupled to discussion with specialists in DEFRA and a recognition of the low numbers of pure beef animals in the applicant states. Low eligibility rates are expected for the Suckler Cow Premium and Beef Special Premium (especially for steer payments).

\section{Sheep}

Headage limit - the highest value of the three years 1997-1999.

LFA supplement eligibility set at 75\% (roughly equal to EU15 shares and noting that sheep tend to be farmed in places with limited alternatives, thus national variations in LFA land are built-in to sheep numbers.) 